\title{
TOWARDS A TYPOLOGY OF DEFINITIONS FOR LSP DICTIONARIES
}

\author{
Deny Arnos Kwary* \\ Aarhus University
}

\begin{abstract}
Definitions are the pivotal parts of dictionaries. Every lexicographer always strives to write definitions which are not only accurate but also comprehensible to dictionary users. Nevertheless, as shown in this paper, the definitions used in the current LSP dictionaries have not been able to suit the needs of their users. Therefore, it is necessary to create a typology of definitions for LSP dictionaries which can be referred to by lexicographers when writing definitions. The typology is created by implementing the lexicographical function theory which focuses on satisfying user needs. The typology takes into account both text production and text reception functions, as well as encyclopaedic and foreign language competences of the users. The proposed typology is expected to serve as a model which can be referred to by lexicographers when deciding on how to write definitions for LSP dictionaries in general, and ESP dictionaries in particular.
\end{abstract}

Keywords: Lexicography, LSP dictionary, ESP, lexicographical functions, text reception and text production.

\footnotetext{
Correspondence should be sent to: Deny Arnos Kwary. Research Assistant, PhD. Department of Business Communication. School of Business and Social Sciences, Aarhus University. Fuglesangs Allé 4, DK-8210 Århus V, Denmark. E-mail: deny@kwary.net
} 


\title{
HACIA UNA TIPOLOGÍA DE DEFINICIONES PREVISTAS PARA DICCIONARIOS DE LENGUAJE ESPECIALIZADO
}

\begin{abstract}
RESUMEN. Las definiciones constituyen el eje principal de los diccionarios. Cualquier lexicógrafo siempre pretende redactar definiciones que son no solo precisas sino también comprensibles para los usuarios. No obstante, como se desprende de este artículo, las definiciones usadas en los diccionarios existentes de lenguaje especializado no han podido cumplir con las exigencias de los usuarios. Por lo tanto, es necesario crear una tipología de definiciones destinadas a los diccionarios de lenguaje especializado que puedan aplicar los lexicógrafos a la hora de redactar las definiciones. Esta tipología se crea en base a la implementación de la teoría de funciones lexicográficas que se centra específicamente en satisfacer las necesidades de los usuarios tomándose en cuenta las funciones de tanto la producción como la recepción asi como los conocimientos enciclopédicos y de lenguas extranjeras de los usuarios. La tipología propuesta se prevé que les sirva de referencia a los lexicógrafos en sus consideraciones de cómo redactar definiciones para diccionarios de lenguaje especializado en general y de inglés para propósitos especificos en particular.
\end{abstract}

Palabras clave: Lexicografía, diccionarios para lenguaje especializado, inglés para fines específicos, funciones lexicográficas, recepción de textos y producción de textos.

\section{INTRODUCTION}

Most dictionary users consult dictionaries to find definitions of words they have problems with. Consequently, definitions are the most commonly used lexicographical descriptions of lemmata or entry words in dictionaries (Atkins and Rundell 2008: 163). The role of definitions is even more crucial in LSP dictionaries in general and ESP dictionaries in particular, because the lexicographers need to have a good command of the specific subject-field or to work together with the subject field specialists in writing the definitions.

An investigation of the definitions used in one type of LSP dictionaries, i.e. financial dictionaries reveals the facts that the lexicographers have not taken into consideration the dictionary functions and users when writing definitions. As a result, the dictionaries have not been able to satisfy the needs of the users optimally. The problems rooted in the current financial dictionaries may result from the lack of theoretical foundation when creating the dictionaries. Several lexicographers have urged the necessity to use a sound lexicographical theory in the conception and construction of lexicographical tools (for a detailed discussion, 
see Verlinde and Leroyer 2010: 1-5). Therefore, when writing the definitions for LSP dictionaries, lexicographers should start their work by considering a theoretical approach which can give the highest benefit for the potential dictionary users.

\section{THEORETICAL FOUNDATION}

In this article, the underlying theory used to formulate the typology of definitions for LSP dictionaries is the lexicographical function theory. There are two main reasons for choosing this theory. The first is its transformative nature. Tarp (2008: 84) explains that this theory is transformative because it does not only lead to improved dictionary concepts, but it also lays a solid theoretical foundation for reviews and criticism of dictionaries that do not perform their role optimally as utility tools. Its transformative nature also means that it does not rely on the solutions offered by current dictionaries but strives to produce new and better solutions to lexicographical problems. The second reason for selecting this theory is its focus on dictionary users. As mentioned in Section 1, the current financial dictionaries are unable to provide optimal help to their potential users, which may be due to the lack in user-centred research.

The lexicographical function theory has been developed at the Centre for Lexicography of Aarhus School of Business, Denmark, since the early 1990s (see Tarp 1992, 2002, 2008, Nielsen 1994, Bergenholtz and Tarp 1995, 2002, 2003, and Bergenholtz and Nielsen 2006). This theory has been mentioned as one of the important and more recent contributions in the field of theoretical lexicography (Gouws 2007: 66). In addition, Tono (2010: 1) states that the lexicographical function theory "is very theoretical in orientation, but, at the same time, very practical in actual applications." Therefore, this article selects this function theory as the theoretical foundation.

The modern theory of lexicographical functions requires lexicographers to determine the function of the dictionary at the initial stage of creating the dictionary. Tarp (2008: 81) defines a lexicographical function as "the satisfaction of the specific types of lexicographically relevant need that arise in a specific type of potential user in a specific type of extra-lexicographical situation." In relation to the topic of this article, the lexicographical function can be defined as the satisfaction of the need to find the meaning of a word; this need arises when a dictionary user has a problem with a particular word and consults an LSP dictionary to find the solution of his/her problem.

Before presenting the application of the lexicographical function theory in writing definitions, this article will first continue by reviewing some examples of definitions used in the current financial dictionaries in the English language. The review tries to visualize the experience of the potential dictionary users when 
consulting the financial dictionaries to find the solutions to their lexicographical problems. The considerations on the dictionary functions and the user competences, which are the principal elements of the lexicographical function theory, are used throughout the review in order to establish the value of providing definitions which are suited to the need of the users.

\section{REVIEWING EXAMPLES OF DEFINITIONS USED IN THE CURRENT FINANCIAL DICTIONARIES}

A list of definitions taken from several financial dictionaries can be obtained from The Free Dictionary website by Farlex. Table 1 shows the search result for the definitions of the term common stock in this dictionary website (http:// financial-dictionary.thefreedictionary.com/ accessed on 8 December 2010). Since this dictionary is available for free and does not establish its specific user group, we can assume that most of the users of this dictionary are lay-people, or those who do not have expertise in finance. Imagine a layman who wants to know the meaning of the term common stock and is presented with the search result in Table 1.

Table 1. Search result for the definitions of common stock

Securities that represent equity ownership in a company. Common shares let an investor vote on such matters as the election of directors. They also give the holder a share in a company's profits via dividend payments or the capital appreciation of the security. Units of ownership of a public corporation with junior status to the claims of secured/unsecured creditors, bondholders and preferred shareholders in the event of liquidation.

Copyright (c) 2004, Campbell R. Harvey. All Rights Reserved.

A class of capital stock that has no preference to dividends or any distribution of assets. Common stock usually conveys voting rights and is often termed capital stock if it is the only class of stock that a firm has outstanding (that is, the firm has neither preferred stock nor multiple classes of common stock). Common stockholders are the residual owners of a corporation in that they have a claim to what remains after every other party has been paid. The value of their claim depends on the success of the firm.

Wall Street Words: An A to Z Guide to Investment Terms for Today's Investor by David L. Scott. Copyright (C) 2003 by Houghton Mifflin Company. Published by Houghton Mifflin Company. All rights reserved. 
Stock in a publicly-traded company that entitles holders to vote in the annual meeting, to elect the board of directors, and to generally exercise control of the company. While common stockholders are important in terms of their level of control, they have the least precedence in the event of liquidation. That is, if the company goes bankrupt, common stockholders do not receive any money until all bondholders, other debt holders, and preferred shareholders are paid in full. Likewise, common stock is not entitled to a guaranteed dividend.

Farlex Financial Dictionary. (c) 2009 Farlex, Inc. All Rights Reserved.

When you own common stock, your shares represent ownership in the corporation and give you the right to vote for the company's board of directors and benefit from its financial success.

You may receive a portion of the company's profits as dividend payments if the board of directors declares a dividend. You also have the right to sell your stock and realize a capital gain if the share value increases.

But if the company falters and the price falls, your investment could lose some of or all its value.

Dictionary of Financial Terms. Copyright (c) 2008 Lightbulb Press, Inc. All Rights Reserved.

A security that represents ownership in a corporation; holders of common stock exercise control by electing a board of directors and voting on corporate policy. Common stockholders are on the bottom of the priority ladder if a company fails. In the case of liquidation, common shareholders get paid after bondholders, preferred shareholders, and other debtholders. In the United Kingdom, common stock is called ordinary shares.

Investopedia's Guide To Wall Speak, Edited by Jack Guinan. Copyright (c) 2009 by Investopedia ${ }^{\circledR}$. Used with permission of The McGraw-Hill Companies, Inc.

Shares in the ownership of a corporation that are entitled to residual dividends, after bonds and preferred stock have first received interest and dividends. A common stockholder usually has a vote in deciding company affairs, including the election of a corporation's board of directors.

Copyright (C) 2008 H\&R Block. All Rights Reserved. Reproduced with permission from H\&R Block Glossary

When looking at the search result in Table 1, the user may be confused of choosing the right definition from the six different definitions provided. In addition, the user will have to spend much time to read the whole definitions. A good dictionary, especially an online dictionary, should be able to quickly give the correct answer to the user's question (Bergenholtz and Gouws 2010: 119). 
Presenting six different definitions will mean that the correct answer cannot be obtained quickly. Thus, such a dictionary cannot qualify as a good dictionary.

If we refer to the research made by Tono (2001: 161) that users always tend to choose the first definition when they are presented with several options, we can assume that this user will choose the first definition listed in Table 1. If we look at the way the definition is written, in particular the use of terms in the definition, it is unlikely that the user will be able to understand it. The first definition, which is written by Harvey, a professor of finance from Duke University, is suited for experts or perhaps, to some extent, to semi-experts in finance, but not for laypeople. Therefore, it is necessary for the dictionary to specify their intended user group, so that people who do not belong to that user group will not waste their time using the dictionary.

An example of a financial dictionary that specifies its user group is the Finance and Business Dictionary by QFINANCE. In the first page of the dictionary website, we can find a statement that the intended users of this dictionary are finance professionals (http://www.qfinance.com/dictionary accessed on 8 December 2010). The following is the definition of the term common stock taken from this Finance and Business Dictionary.

\section{common stock}

a stock that provides voting rights but only pays a dividend after dividends for preferred stock have been paid.

The definition may not be easily understood by lay-people because of the use of technical words (e.g. dividend and preferred stock) in the definition, but it is adequately comprehensible to finance professionals or experts who are the target users of the dictionary. It can be argued, however, that it is unlikely for an expert in finance to have a text reception problem and consult a financial dictionary to find the meaning of a financial term (Bergenholtz and Kaufmann 1997: 102). Therefore, a text reception LSP dictionary intended for experts in their subject field may not be quite useful. This Finance and Business Dictionary can be more useful if it is for text production. Unfortunately, as we can see from the dictionary article above, the lemma common stock is not accompanied with additional data which can help in text production. Some examples of the additional data which are useful for text production are word class, collocations, and derivatives (for a detailed discussion, see Tarp 2008: 149-153). In addition, the definitions in the Finance and Business Dictionary are not written according to the full-sentence structure, which is useful for text production dictionaries, especially in assisting the users with the grammatical patterns of the words (Rundell 2006: 740). The following section explains the language structures which should be considered by LSP lexicographers when writing definitions for text production and text reception dictionaries. 


\section{DEFINITIONS BASED ON DICTIONARY FUNCTIONS}

Before establishing the language structure which is most suitable to be used when writing definitions for text production and text reception LSP dictionaries, it is necessary to describe the two language structures widely used in LGP (language for general purposes) or learner dictionaries. The merits and demerits of these two language structures will then be associated with the dictionary functions in order to determine which type of language structure is more suitable for which dictionary function. The two language structures which are widely used in LGP dictionaries are: substitutable definitions and full sentence definitions. The description of these language structures are given in the following paragraphs.

To illustrate the difference between the substitutable definitions and full sentence definitions, consider some definitions of the verb raise. A dictionary that uses a substitutable definition will define the verb raise as 'to lift, push, or move upwards' (Longman Dictionary of Contemporary English 1987). A dictionary that uses a full sentence definition will define it as 'If you raise something, you move it so that it is in a higher position' (Collins COBUILD Advanced Learner's English Dictionary 2006). One of the advantages of the full sentence definitions is the implicit ability to tell the users about the structure of the words. In this example, the full sentence definition enables the user to guess that the verb raise needs to be followed by an object. A user who is familiar with the term transitive will know from the definition that it is a transitive verb. In contrast, the user cannot draw the same inference if the dictionary uses a substitutable definition. Given this advantage, Cowie (1999: 169) calls the full sentence definition a sophisticated outgrowth. In addition, Rundell (2006: 740) notes that most of the current English monolingual dictionaries have widely used the full sentence definitions, whereas substitutable definitions are claimed to be the feature of traditional lexicography.

Table 2. The primary structure of the full sentence definition

\begin{tabular}{|l|l|l|l|l|l|}
\hline \multicolumn{5}{|c|}{ FIRST PART } & \multicolumn{1}{c|}{ SECOND PART } \\
\hline Operator & Co-text (1) & Topic & Co-text (2) & Operator & \multicolumn{1}{c|}{ Comment } \\
\hline & a & house & & is & a building in which people live \\
\hline when & artists & exhibit & & & they show their work in public \\
\hline & a & pure & substance & is & not mixed with anything else \\
\hline if & $\begin{array}{l}\text { something } \\
\text { happened }\end{array}$ & often & & & $\begin{array}{l}\text { it happens many times or } \\
\text { much of the time }\end{array}$ \\
\hline
\end{tabular}


The idea of full sentence structure in writing definitions in English monolingual dictionaries was introduced into COBUILD dictionaries in 1987. Sinclair (1991: 124125) mentions that the primary structure of full sentence definitions is divisible into two principal parts as shown in Table 2. In this table, Sinclair uses the term topic to refer to the lemma.

The two-part structure in Table 2 places the defined words in contexts where the words are used. Therefore, it can be assumed that the full sentence definitions are useful for text production dictionaries. Although Rundell (2006: 739) states that monolingual learner dictionaries are intended to satisfy both text production and text reception functions, the full sentence structure used in monolingual learner dictionaries seems to work better in text production than in text reception.

Table 3 compares a full sentence definition with a substitutable definition for a lemma which can be found in an LSP dictionary, in particular a financial dictionary. In the first column of Table 3 is the full sentence definition which is a modified version of the definition given in the Collins COBUILD English Dictionary for Advanced Learners (2001). The original definition from the COBUILD dictionary is 'If one thing merges with another, or is merged with another, they combine or come together to make one whole thing.' On the second column of Table 3 is the substitutable definition which is created by the author of this article. The financial term or lemma used in this comparison is the verb merge.

Table 3. Comparing the full sentence definition with the substitutable definition

\begin{tabular}{|l|l|}
\hline \multicolumn{1}{|c|}{ Full sentence definition } & \multicolumn{1}{c|}{ Substitutable definition } \\
\hline Merge & Merge \\
If one business merges with another, & to combine two or more businesses \\
or is merged with another, they com- & into one. \\
bine or come together to make one & \\
whole business. & \\
\hline
\end{tabular}

The full sentence definition is longer than the substitutable definition because it contains two parts instead of one. In addition, it has to be noted that a full sentence definition does not only mean simply writing a definition in a full sentence, but it also has to be able to show the common structure of the lemma. This is usually carried out by considering the concordance results or the KWIC (Key Word in Context). In the above example, the language structure in the full sentence definition informs the users that the verb merge can be used in active and passive forms, and is followed by the preposition with. Therefore, the full sentence definitions are important for text production, but they are not very useful for text reception where the users only need to know the meaning of the term in the quickest way. 
The substitutable definition comprises only the comment of the second part in Table 2. Therefore, as shown in Table 3, the substitutable definition provides a shorter definition and focuses directly on the meaning of the word. The substitutable definition consists of fewer words, so users do not need to spend much time reading it. In a text reception situation, a user is reading a text and $\mathrm{s} /$ he needs to find the meaning of a particular word in the fastest possible way, so that $\mathrm{s} /$ he can continue his/her reading process right away. Therefore, it is a good idea to provide a definition that is as concise as possible. This means that for a text reception function, the substitutable definitions can be considered as being more suitable to satisfy the needs of the users than the full sentence definitions.

Based on the explanation above, it is reasonable to conclude that the function of a dictionary determines the kind of language structure to be used in writing the definitions. This is illustrated in Figure 1. If the main function of a dictionary is for text production, it is advisable to use the full sentence structure in writing the definitions. If the main function of a dictionary is for text reception, it is better to use the substitutable definitions. After determining the language structure of the definitions, the next step is to consider the content and the language used in the definitions. This is closely related to the user competences, which are explained in the following section. The discussion is focused on the text reception function, not only because most users consult LSP dictionaries to solve their text reception problems, but also in order to make an in-depth analysis of a particular dictionary function.

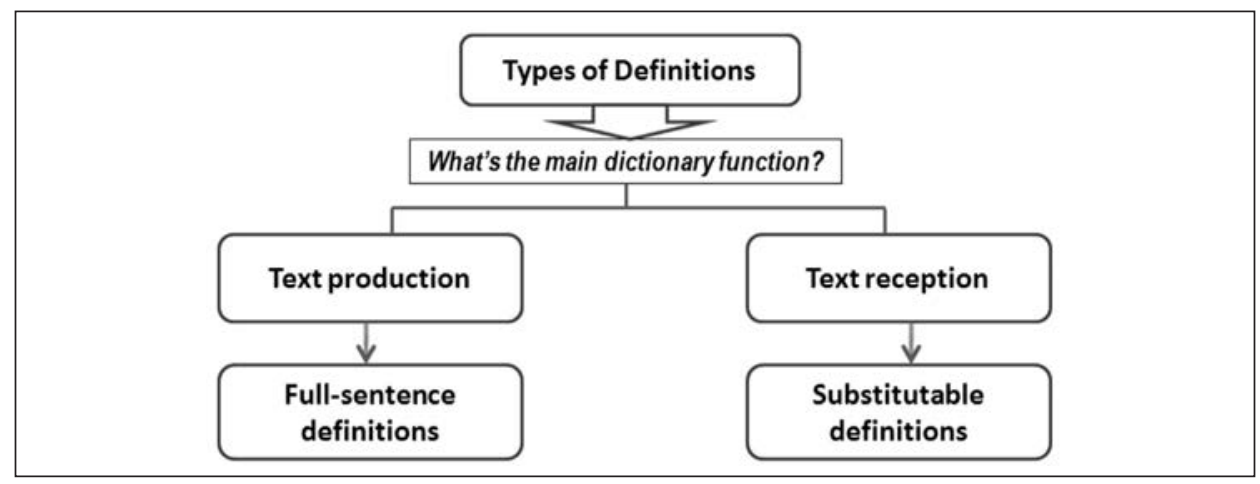

Figure 1. Types of definitions based on dictionary functions.

\section{DEFINITIONS BASED ON USER COMPETENCES}

LSP dictionary users have different competences and these may influence the way the definitions in LSP dictionaries is written. Bergenholtz and Tarp (1995: 21) distinguish between different groups of LSP dictionary users based on 
two types of competences: encyclopaedic (subject-field) competence and foreign language competence. The consideration on the users' encyclopaedic competence is applicable to LSP dictionaries for both native speakers and foreign language speakers. However, the users' foreign language competence is only taken into account when creating LSP dictionaries targeted for foreign language users. Since there are more users of English financial dictionaries who are not native speakers of English, this article will include both the encyclopaedic and foreign language competences in proposing a typology of definitions for LSP dictionaries.

Based on their foreign language competence, LSP dictionary users can be classified into advanced, intermediate and beginner levels. These different levels of competences determine the language that should be used in writing the definitions. If the targeted dictionary users are at a beginner level in the foreign language, it is advisable to use the users' native language in defining the lemmata. Conversely, if the users are at an advanced level in the foreign language, it is recommended that the foreign language is used in defining the lemmata. The problem is when the users are at an intermediate level in the foreign language, because there are some lemmata which are better explained in the native language and some other in the foreign language (for a detailed discussion, see Kwary (2010: 1112-1118). Figure 2 illustrates the typology of definitions which takes the dictionary functions and the users' foreign language into consideration.

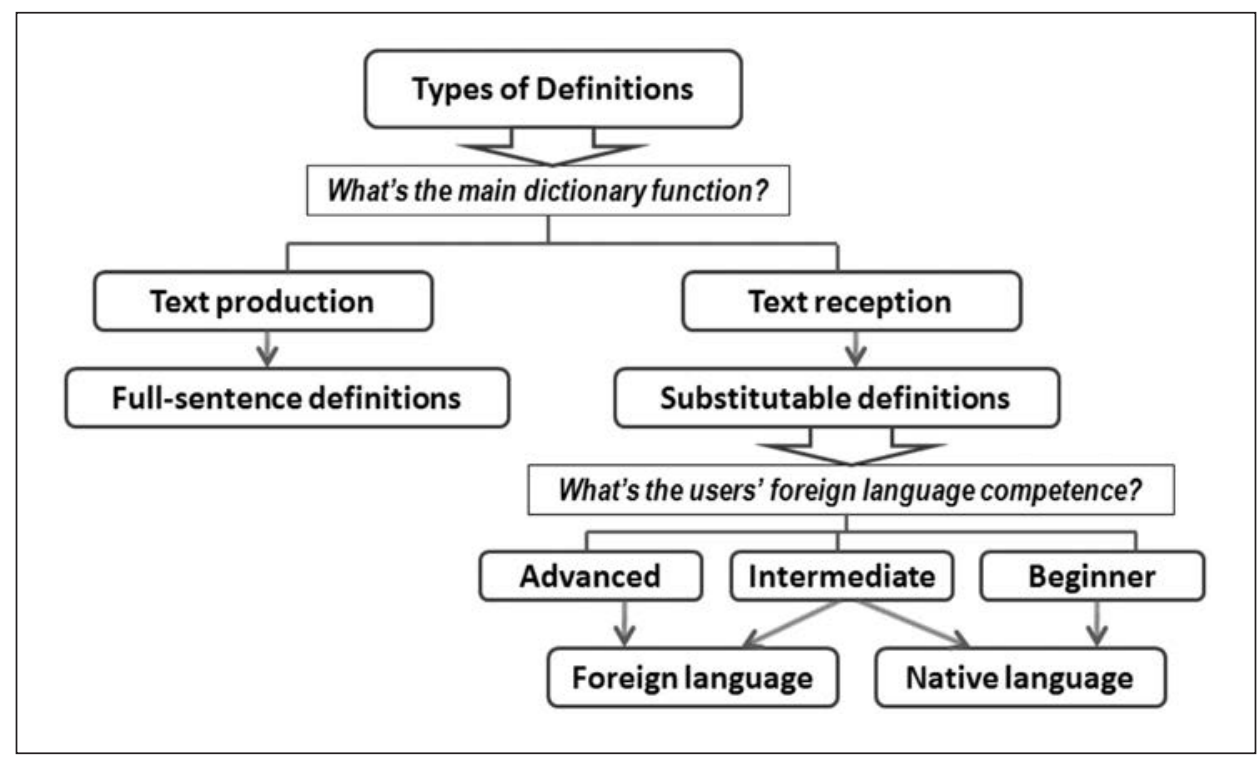

Figure 2. Types of definitions based on the dictionary functions and the users' foreign language competence. 
Next, according to their encyclopaedic or subject-field competence, LSP dictionary users can be categorized into experts, semi-experts, and laypeople (Bergenholtz and Tarp 1995: 21). Accordingly, LSP dictionaries targeted at users with different competence category should contain different types of definitions as well. Bergenholtz and Nielsen (2006: 299) give the following example for the definition of the term gene if the user is a layman and is reading a text on gene technology.

\section{gene}

the basic unit of inheritance which is transmitted from parents to offspring.

In the same situation, if the user is a semi-expert, Bergenholtz and Nielsen (2006: 300) suggest the following definition:

gene

a gene is a DNA sequence ending a mRNA (protein), tRNA or rRNA.

The above examples show that the main difference in the definition for layman and for semi-expert is not in the length of the definitions but on the exactness and the scientific terms used in the definitions. The definition given to a layman will not be useful to a semi-expert, due to the lack of exactness; whereas, the definition provided for a semi-expert will not be understandable to a layman due to the lack of knowledge of the subject-field and the use of technical vocabulary. Those examples confirm that users who have different levels of mastery of the subject field require different types of definitions.

The necessity to provide different definitions for users with different subjectfield competences is not only applied to scientific dictionaries such as a dictionary of gene technology exemplified above. The same requirement should also be applied to other LSP dictionaries. For example, imagine a user who is reading a financial text, finds the term common stock and consults a dictionary to find its definition. If this user is a layman, s/he should be presented with the following dictionary article:

\section{common stock}

a type of share in a company that gives the owner the right to receive an amount of money from the company, and the right to vote at meetings.

If the user is a semi-expert, a more exact definition is required, such as the following:

common stock

A type of share that gives the owner the right to receive an amount of money according to how much profit the company has made, and the right to vote at stockholder meetings. 
The definition for a semi-expert, as shown above, gives a more exact definition regarding the amount of money that the stockholder can receive (i.e. based on how much profit the company has made). If the user is an expert, the dictionary should provide the following definition which is even more exact and uses technical vocabulary which is understandable to an expert.

\section{common stock}

A type of share that gives the owner the right to a dividend, and the right to vote at stockholder meetings.

The term dividend is used in the expert definition to provide the user with a more exact method of calculating the money received by the stockholder and to enable the user to identify the amount of the money in a financial statement. For practical reasons, however, text reception dictionaries rarely use expert definitions because, as stated by Bergenholtz and Kaufmann (1997: 102), experts in the particular subject field will not have text reception problems. Therefore, LSP lexicographers who make dictionaries with text reception function should consider whether to use the layman definitions or the semi-expert definitions depending on the subject-field competence of their targeted dictionary users.

In text production, however, LSP lexicographers may need to consider using the expert definition as well if their targeted dictionary users are experts, because experts may have text production problems. For example, a financial professional does not have a problem to understand the meaning of the term security in the financial sense. However, this financial professional might want to know whether this term is countable or uncountable, in other words, whether there is a plural form of this term or not. The incorporation of the encyclopaedic and foreign language competences in writing definitions for LSP dictionaries is described in the next section.

\section{A TYPOLOGY OF DEFINITIONS FOR LSP DICTIONARIES}

The decision on how to write definitions for LSP dictionaries requires a clearcut typology or classification on the types of definitions which are suitable to the dictionary function and the user competences. Figure 3 presents a proposal for a typology of definitions for LSP dictionaries. The typology is divided into three stages which comprise questions that should be considered by LSP lexicographers when determining the type of definitions they should use in the dictionaries.

As shown in Figure 3, there are three questions that lexicographers should consider before writing the definitions for the LSP dictionaries they are going to create. The first question to be asked is what the dictionary function is. As explained in Section 4, if the main function of the dictionary is for text production, 
it should use the full sentence definitions, whereas if the main function is for text reception, it should use the substitutable definitions.

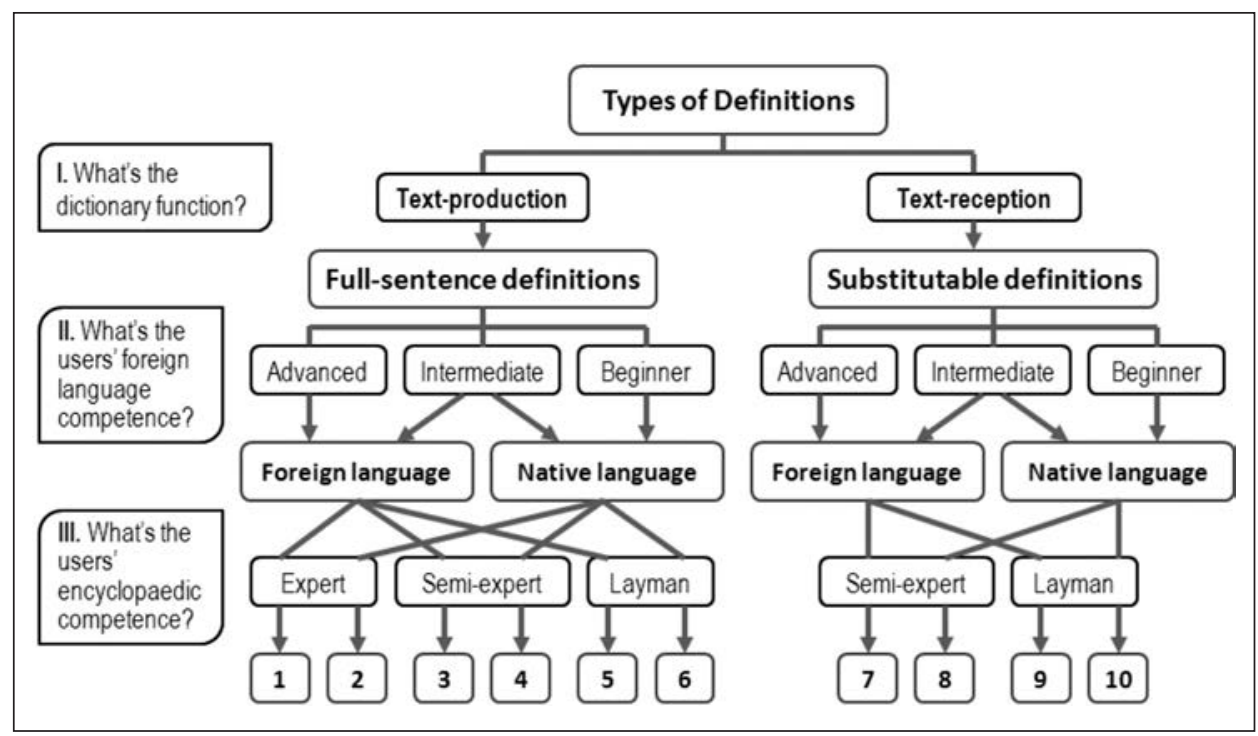

Figure 3. A typology of definitions for LSP dictionaries.

Next, the second question to be asked is what the users' foreign language competence is. At this stage, the users can be categorized into three groups or levels: beginner, intermediate, and advanced. If the users are at a beginner level in the foreign language, the definitions should be written in the native language of the users. If the users are at an advanced level in the foreign language, the definitions should be written in the the foreign language. If the users are at an intermediate level in the foreign language, two options should be provided: definitions in the users' native language and in the foreign language.

Finally, the last question is what the users' encyclopaedic competence is. For this type of competence, the users can be classified into layman, semi-expert and expert if the dictionary is for text production. However, as explained in Section 5, if the dictionary is for text reception, the users can be grouped into either layman or semi-expert. Consequently, lexicographers have the following ten options that they can choose when writing the definitions for LSP dictionaries:

1. Full sentence definitions, written in the foreign language, with content suitable for experts.

2. Full sentence definitions, written in the native language, with content suitable for experts. 
3. Full sentence definitions, written in the foreign language, with content suitable for semi-experts.

4. Full sentence definitions, written in the native language, with content suitable for semi-experts.

5. Full sentence definitions, written in the foreign language, with content suitable for laypeople.

6. Full sentence definitions, written in the native language, with content suitable for laypeople.

7. Substitutable definitions, written in the foreign language, with content suitable for semi-experts.

8. Substitutable definitions, written in the native language, with content suitable for semi-experts.

9. Substitutable definitions, written in the foreign language, with content suitable for laypeople.

10. Substitutable definitions, written in the native language, with content suitable for laypeople.

These various options might be difficult to implement altogether in printed dictionaries. However, it is not the case for online dictionaries, because one dictionary website can accommodate more than one option that the users can choose by simply clicking a particular button. One database for an online dictionary has the ability to accommodate more than one dictionary. For example, the online financial dictionary by Farlex, mentioned in Section 2, accommodates six financial dictionaries as follows:

1. Hypertextual Finance Glossary, 2004.

2. Wall Street Words: An A to Z Guide to Investment Terms for Today's Investor, 2003.

3. Farlex Financial Dictionary, 2009.

4. Dictionary of Financial Terms, 2008.

5. Investopedia's Guide to Wall Speak, 2009.

6. HER Block Glossary, 2008.

It is a good idea to integrate different dictionaries into one dictionary website. However, the different dictionaries should not only be selected based on their availability, but on their potential benefits for the users. If they are not beneficial to meet the needs of the users, they should not be included. In this case, it is recommended to accommodate dictionaries which support one another and beneficial for the users. An example on how to implement the typology in Figure 3 into an online LSP dictionary is described in the following paragraphs. 
Take, for instance, a lexicographer who is going to make an English dictionary of finance which is aimed at university students in Indonesia. Since Indonesian students studying in business schools in Indonesian universities do not need to write their assignments in English, they do not really need a dictionary for text production. However, since they have to read a lot of financial texts in English, they need a dictionary which can help them solve their text reception problems. Therefore, at stage one in Figure 3, the lexicographer decides that the main function of the dictionary is for text reception and will use substitutable definitions.

Next, the lexicographer needs to determine the users' foreign language competence. The students, who are the intended users, have learned English as a foreign language for at least six years, so they cannot be considered at a beginner level, and it will be too exaggerating if they are classified into advanced users of English. Therefore, these users can best be categorized as intermediate in their foreign language competence. Being in an intermediate level, the users can sometimes understand the definitions if they are written in English, and sometimes in Indonesian. Consequently, the lexicographer decides to write the definitions in two languages: English and Indonesian.

Finally, the lexicographer should decide whether these users are lay-people or semi-experts. University students who are in their freshman year can be categorized as lay-people, those who are in their sophomore and junior years can either be called lay-people or semi-experts, and those who are in their senior year can be considered semi-experts. It means that the lexicographer should write the definitions in two types: layman definitions and semi-expert definitions.

To sum up, this online financial dictionary for these Indonesian students should integrate the four options, numbers 7 to 10, in Figure 3. It does not matter whether these four options are called four dictionaries or four tools, as long as they are useful to help the users solve their lexicographical problems. These four options can be converted into four buttons with the following headings:

\section{(1) Layman definition}

(2) Semi-expert definition

(3) Definisi untuk orang awam

(4) Definisi untuk semi-abli

Every lemma in this dictionary has to be accompanied with the four types of definitions mentioned above. It means that there are four possible results for each search action made by the users. For example, if a user has a problem to understand the term issue and consult this dictionary, the possible results of the search action of this user are as follows, depending on which button this user clicks: 
Layman definition $\rightarrow$ The number of shares on offer to the public.

Semi-expert definition $\rightarrow$ A series of stocks or bonds that have been offered to the public.

Definisi untuk orang awam $\rightarrow$ Sejumlah saham yang ditawarkan ke masyarakat umum.

Definisi untuk semi-abli $\rightarrow$ Serangkaian saham atau obligasi yang telah ditawarkan ke masyarakat umum.

The first option, Layman definition, is the best option for users who are in their freshman year and have an English language proficiency at an upper-intermediate level. These users feel comfortable about reading definitions in English but do not know much about finance, i.e. low encyclopaedic competence. This means that for the term issue, the Layman definition ('The number of shares on offer to the public') is the most appropriate one to satisfy their needs to understand the financial terminology. These users can understand this definition because they are quite fluent in English and the definition does not use financial terminology which is incomprehensible to these users.

The second option, Semi-expert definition, is the best option for users who are in their senior year and have an English language proficiency at an upperintermediate level. These users have a good knowledge of finance and feel comfortable in reading English definitions. However, they may want to know the more precise definition of a term. In this case, they can use the option Semi-expert definition ('A series of stocks or bonds that have been offered to the public') to satisfy their needs. These users can understand this definition because they are quite fluent in English and they know the meaning of the terms stocks and bonds which are used in the definition to make it more precise and suitable to the needs of these semi-experts.

The third option, Definisi untuk orang awam ('layman definition in Indonesian'), is the best option for users who are in their freshman year and have an English language proficiency at a lower-intermediate level. These users have low competence in comprehending English language texts, and have not learned much about finance. Therefore, the option Definisi untuk orang awam ('Sejumlah saham yang ditawarkan ke masyarakat umum') is the best option to satisfy their needs because it is a lot easier for them to understand the definitions if they are given in Indonesian than in English. In addition, the definition is only written using general words, so it is easy for them to understand it.

The fourth option, Definisi untuk semi-abli ('semi-expert definition in Indonesian'), is the best option for users who are in their senior year and have an English language proficiency at a lower-intermediate level. These users have learned a lot about finance, but only in the Indonesian language. They do not 
feel comfortable reading the English definitions due to their low English language proficiency. Therefore, they would prefer the option Definisi untuk semi-abli ('Serangkaian saham atau obligasi yang telah ditawarkan ke masyarakat umum') to satisfy their needs. These users can understand this definition very well since it is in the Indonesian language.

In addition to the four options mentioned above, the lexicographer may consider providing another button, i.e. Terjemahan ('equivalents in Indonesian'), or integrating the equivalents at the beginning of the definitions which are written in the native language of the users. This option, however, is related to text translation function which is beyond the topic of this article. The main focus of this article is on writing definitions, not on translations. Therefore, the lexicographical functions discussed are the text production and text reception. The discussion has resulted in a typology of definitions, shown in Figure 3, which can be used by lexicographers when deciding on how to write the definitions in LSP dictionaries.

\section{CONCLUSION}

The type of definitions used in one LSP dictionary should be different from that used in another LSP dictionary if the two dictionaries have different functions and different user groups. This article proposes a typology of definitions which contain ten options or types of definitions that lexicographers can choose when deciding on how to write definitions for LSP dictionaries in general, and ESP dictionaries in particular. The typology comprises three stages: dictionary functions, users' foreign language competence, and users' encyclopaedic competence. This typology is expected to help lexicographers write and address the right definitions for the right dictionary users. Consequently, the dictionaries created will be able to provide optimal solutions to the users' lexicographical problems.

\section{REFERENCES}

Atkins, B. T. S. and Rundell, M. 2008. The Oxford Guide to Practical Lexicography. Oxford: Oxford University Press.

Bergenholtz, H. and Gouws, R. 2010. "A new perspective on the access process". Hermes. Journal of Language and Communication Studies 44: 103-127.

Bergenholtz, H. and Kaufmann, U. 1997. "Terminography and lexicography: A critical survey of dictionaries from a single specialised field". Hermes. Journal of Language and Communication Studies 18: 91-125.

Bergenholtz, H. and Nielsen, S. 2006. "Subject-field components as integrated parts of LSP dictionaries". Terminology, 12 (2), 281-303. 
Bergenholtz, H. and Tarp, S. 1995. Manual of Specialised Lexicography: The preparation of specialised dictionaries. Amsterdam: John Benjamins.

Bergenholtz, H. and Tarp, S. 2002. "Die moderne lexikographische funktionslehre. Diskussionsbeitrag zu neuen und alten paradigmen, die wörterbücher als gebrauchsgegenstände verstehen”. Lexicographica. International Annual for Lexicography 22: 145-155.

Bergenholtz, H. and Tarp, S. 2003. "Two opposing theories: On H. E. Wiegand's recent discovery of lexicographic functions". Hermes. Journal of Language and Communication Studies 31: 171-196.

Cowie, A. P. 1999. English Dictionaries for Foreign Learners: A history. Oxford: Clarendon Press.

Farlex. 2009. Farlex financial dictionary. <http://financial-dictionary. thefreedictionary.com>. (Accessed 8 December 2010).

Gouws, R. H. 2007. "Sublemmata or main lemmata". Dictionary Visions, Research, and Practice. Eds. Gottlieb, H. and J. E. Mogensen. Amsterdam: John Benjamins. 55-69.

Guinan, J. 2009. Investopedia's Guide to Wall Speak. <http://financial-dictionary. thefreedictionary.com>. (Accessed 8 December 2010).

H\&R Block. 2008. HER Block Glossary. <http://financial-dictionary.thefreedictionary. com>. (Accessed 8 December 2010).

Harvey, C. R. 2004. Hypertextual Finance Glossary. <http://financial-dictionary. thefreedictionary.com>. (Accessed 8 December 2010).

Kwary, D. A. 2010. "From language-oriented to user-oriented electronic LSP dictionaries: A Case Study of an English dictionary of finance for Indonesian students". The Proceedings of the 14th Euralex International Congress. Eds. A, Dykstra and T. Schoonheim. Ljouwert: Afuk. 1112-1120.

Light Bulb Press. 2008. Dictionary of Financial Terms. <http://financial-dictionary. thefreedictionary.com>. (Accessed 8 December 2010).

Nielsen, S. 1994. The Bilingual LSP Dictionary: Principles and Practice for Legal Language. Tübingen: Gunter Narr Verlag.

QFinance. 2010. Finance and Business Dictionary. <http://www.qfinance.com/ dictionary>. (Accessed 8 December 2010).

Rundell, M. 2006. "Learners' dictionary". Encyclopedia of Language and Linguistics. Ed. K. Brown. Amsterdam: Elsevier. 739-743.

Scott, D. L. 2003. Wall Street Words: An A to Z Guide to Investment Terms for Today's Investor. <http://financial-dictionary. thefreedictionary.com>. (Accessed 8 December 2010). 
Sinclair, J. M. 1991. Corpus, Concordance, Collocation. Oxford: Oxford University Press.

Sinclair, J. (Ed.) 2001. Collins COBUILD English Dictionary for Advanced Learners. 3rd ed. Glasgow: HarperCollins.

Sinclair, J. (Ed.) 2006. Collins COBUILD Advanced Learner's English Dictionary. 5th ed. Glasgow: HarperCollins.

Summers, D. (Ed.). 1987. Longman Dictionary of Contemporary English. 2nd ed. Essex: Longman.

Tarp, S. 1992. Prolegomena til Teknisk Ordbog. Aarhus: Aarhus School of Business.

Tarp, S. 2002. "Translation dictionaries and bilingual dictionaries: Two different concepts". Journal of Translation Studies 7: 59-84.

Tarp, S. 2008. Lexicography in the Borderland between Knowledge and NonKnowledge: General Lexicographical Theory with Particular Focus on Learner's Lexicography. Niemeyer: Tübingen.

Tono, Y. 2001. Research on Dictionary Use in the Context of Foreign Language Learning. Niemeyer: Tübingen.

Tono, Y. 2010. "A critical review of the theory of lexicographical functions". Lexicon 40: 1-26.

Verlinde, S. and Leroyer, P. 2010. "Search and you will find: From stand-alone lexicographic tools to user driven task and problem oriented multifunctional leximats". International Journal of Lexicography 23 (1): 1-17. 